\title{
Safflower polysaccharide induces NSCLC cell apoptosis by inhibition of the Akt pathway
}

\author{
JIAN-YING LI ${ }^{1,2^{*}}$, JUN YU $^{3,4^{*}}$, XU-SHENG DU ${ }^{2}$, HUI-MIN ZHANG ${ }^{2}$, BO WANG ${ }^{2}$, HUA GUO $^{2}$, \\ $\mathrm{JIE} \mathrm{BAI}^{2}, \mathrm{JUAN}^{-H O N G} \mathrm{WANG}^{5}, \mathrm{AN} \mathrm{LIU}^{2}$ and YI-LI WANG ${ }^{1}$ \\ ${ }^{1}$ Institute of Cancer Research, School of Basic Medical Sciences, Xi'an Jiaotong University, \\ Xi'an, Shaanxi 710061; ${ }^{2}$ Department of Respiratory Disease, Affiliated Xi'an Central Hospital, Medical \\ School of Xi'an Jiaotong University, Xi'an, Shaanxi 710003; ${ }^{3}$ Department of General Surgery, Affiliated \\ Second Hospital, Medical School of Xi'an Jiaotong University, Xi'an, Shaanxi 710003; ${ }^{4}$ Department of General \\ Surgery, Affiliated Xi'an Central Hospital, Medical School of Xi'an Jiaotong University; ${ }^{5}$ Department of Pathology, \\ Affiliated Xi'an Central Hospital, Medical School of Xi'an Jiaotong University, Xi'an, Shaanxi 710003, P.R. China
}

Received December 21, 2015; Accepted January 30, 2016

DOI: $10.3892 /$ or.2016.4784

\begin{abstract}
Lung cancer is the leading cause of cancer death in the world. Safflower polysaccharide (SPS) has been used for the improvement of immunomodulatory activities and treatment of cancers. However, studies on the effect of SPS on the progression of lung cancer have rarely been reported. To study the antitumor effect of SPS on human lung cancer and its potential mechanism, non-small cell lung cancer cell lines (NSCLC), A549 and YTMLC-90 were treated with SPS at various concentrations ranging from 0.04 to $2.56 \mathrm{mg} / \mathrm{ml}$ and $\mathrm{BALB} / \mathrm{c}$ nude tumor-bearing mice were injected intraperitoneally with SPS at concentrations ranging from 15 to $135 \mathrm{mg} / \mathrm{kg}$. Results showed that SPS suppressed the proliferation of A549 and YTMLC-90 cells and induced apoptosis by increasing mRNA levels of bax and caspase-3, and inhibited tumor growth in vivo. SPS induced cell cycle arrest in the $\mathrm{G} 2 / \mathrm{M}$ phase by decreasing the expression of cdc25B and cyclin B1. Moreover, SPS decreased the expression of Akt, p-Akt and PI3K. In mice, SPS injection enhanced immunomodulatory activities by increasing levels of TNF- $\alpha$ and IL-6 in tumor-bearing mice. Our findings suggest that SPS suppresses tumor growth by enhancing immunomodulatory activities and blocking the PI3K/Akt pathway. This study provides new insight into the anticancer mechanism of SPS.
\end{abstract}

Correspondence to: Dr Yi-Li Wang, Institute of Cancer Research, School of Basic Medical Sciences, Xi'an Jiaotong University, Xi'an, Shaanxi 710061, P.R. China

E-mail: yiliwangs@163.com

*Contributed equally

Key words: safflower polysaccharide, non-small cell lung cancer, apoptosis, PI3K/Akt, immunomodulation ativities

\section{Introduction}

Lung cancer is the leading cause of cancer death all over the world. It is classified into two main histological groups: nonsmall cell lung cancer (NSCLC, 85\%) and small cell lung cancer (SCLC, 15\%) (1). The 5-year survival rate for lung cancer is only $16 \%$ (2). Therefore, it is necessary and critical to find a novel approach to increase the survival rate of lung cancer.

The phosphatidylinositol-3kinase (PI3K)/Akt signaling pathway is vital to cell growth and apoptosis (3). Many studies have reported that the PI3K/Akt signaling pathway was aberrantly activated in lung cancer (4-6). Some anticancer-drugs downregulated the expression of Akt and induced G2/M phase arrest. The G2/M checkpoint is regulated by cdc $25 \mathrm{~B}$ and cyclin B1 (7). For example, knocking down Sox 2 induced $\mathrm{G} 2 / \mathrm{M}$ arrest by decreasing expression levels of cyclin B1 and cdc2 in lung squamous cell carcinomas (8). Genistein induced cell cycle arrest in the G2/M phase by downregulating expression levels of cyclin B1 and cdc25B in H446 NSCLC (9).

Carthamus tinctorius L. (C. tinctorus), commonly named safflower, is a herbal plant in the family compositae. Safflower is well known for its function in the promotion of blood flow, removal of blood stasis, promotion of menstruation and alleviation of pain (10). The active components of safflower are quinochalones, flavonoids, alkaloids, and safflower polysaccharide (SPS). In recent years, many pharmacological experiments have demonstrated that safflower has a wide variety of biological activities, including the improvement of acute ischemic stroke (11-13) and the enhancement of antiinflammation (14), antioxidant (15), antitumor (16), and antibacterial activities (17). SPS is one of the most important active components and is used for modulating the immune system and cancer prevention. However, the effect of SPS on lung cancer progression is rarely reported and the underlying mechanisms remain unknown. In this study, we investigated the effect of SPS on the proliferation of A549 and YTMLC-90 cell lines. We also focused on the underlying mechanisms of SPS on the cell cycle and apoptosis in A549 and YTMLC-90 
cells. We observed that SPS induced NSCLC cell apoptosis by enhancing immunomodulatory activities and blocking the PI3K/Akt signaling pathway. This study provides new insights into the anticancer mechanism of SPS.

\section{Materials and methods}

Chemicals and reagents. RPMI-1640 medium, heat-inactivated fetal bovine serum (FBS), penicillin and streptomycin, and 3-(4,5-dimethylthiazol-2-yl)-2,5-diphenyltetrazolium bromide (MTT) were obtained from Sigma Chemical Co. (St. Louis, MO, USA). ELISA kits were from Shanghai Enzme-linked Biotechnology Co., Ltd. (Shanghai, China). BALB/c nude mice were from Vital River Laboratory Animal Technology Co. Ltd., Beijing, China. Antibodies to cyclin B1, Cdc25B, PI3K, Akt and p-Akt were purchased from Abcam (Cambridge, MA, USA). The PrimeScript ${ }^{\mathrm{TM}}$ RT-PCR kit and SYBR Premix Ex $\mathrm{Taq}^{\mathrm{TM}}$ kit were obtained from Takara (Takara, Kusatsu, Japan).

Ethical standard. All procedures performed in studies involving animals were in accordance with the ethical standards of the Authors' institution.

Preparation of SPS. SPS (AR, 90\%) was purchased from Xi'an Reain Biotechnology Co. Ltd, Xi'an, China. The SPS was dissolved with DMSO to different concentrations: 0.04, 0.08, $0.16,0.32,0.64,1.28$, and $2.56 \mathrm{mg} / \mathrm{ml}$.

Cell culture and treatment. Human lung cancer cell lines, A549 and YTMLC-90 were purchased from the Cell Library Committee on Type Culture Collection of the Chinese Academy of Sciences, Beijing. Cells were cultured in RPMI-1640 supplemented with $10 \%$ fetal bovine serum (FBS), $100 \mathrm{U} / \mathrm{ml}$ penicillin and $100 \mu \mathrm{g} / \mathrm{ml}$ streptomycin in a humidified, $5 \% \mathrm{CO}_{2}$ atmosphere at $37^{\circ} \mathrm{C}$. The cells were plated at a density of $10^{5}$ cells per well and grown for $24 \mathrm{~h}$.

MTT assay. The MTT assay was used to evaluate cell viability. Cells were seeded in 96 -well plates at a density of $5 \times 10^{3}$ cells per well and grown for $24 \mathrm{~h}$. Cells were then treated with various concentrations of SPS ranging from 0.04 to $2.56 \mathrm{mg} / \mathrm{ml}$ for 24 , 48 , and $72 \mathrm{~h}$. Cells treated with an equivalent volume of DMSO were regarded as the control groups. Each group was treated in triplicate. Following treatment, $10 \mu \mathrm{l}$ MTT was added to each well and incubated for $4 \mathrm{~h}$. Finally, blue formazan crystals of viable cells were solubilized in $100 \mu \mathrm{l}$ DMSO. The absorbance was measured at $450 \mathrm{~nm}$ using a microplate reader.

Flow cytometric analysis of apoptosis. Apoptosis was assessed in A549 and YTMLC-90 cells using an Annexin V-FITC/propidium iodide (PI) staining assay. Cells were cultured in 6-well plates at a density of $2 \times 10^{5} / \mathrm{ml}$ per well overnight. Cells were then treated with various concentrations of SPS ranging from 0.04 to $2.56 \mathrm{mg} / \mathrm{ml}$ for $48 \mathrm{~h}$. Control cells were treated with culture medium containing DMSO. Each group was treated in triplicate. After treatment, cells were washed with cold PBS and resuspended in binding buffer (100 mM HEPES, pH 7.4, $100 \mathrm{mM}$ $\mathrm{NaCl}, 25 \mathrm{mM} \mathrm{CaCl}_{2}$ ). Cells were stained with Annexin V-FITC/ PI at $4^{\circ} \mathrm{C}$ for $30 \mathrm{~min}$. Apoptotic cells were analyzed using a fluorescence-activated cell-sorting (FACS) flow cytometer.
Real-time PCR. The expression levels of bax, caspase-3 and $c d c 25 B$ were measured using real-time PCR. Cells were treated with various concentrations of SPS ranging from 0.04 to $2.56 \mathrm{mg} / \mathrm{ml}$ for $48 \mathrm{~h}$. Following treatment, cells were collected and their total RNA extracted using TRIzol reagent. cDNA was synthesized using the PrimeScript RT-PCR kit (Takara). Real-time PCR was performed using SYBR Premix Ex Taq kit (Takara). Primer sequences were as follows: cdc25B: 5'-TTC ATC AGG GAA CGA GA CCG TG-3', 5'-TTC ACA GAA GTT CGG GTG CTG AG-3'; bax: 5'-GGA GCT GCA GAG GAT GAT TG-3', 5'-CCT CCC AGA AAA ATG CCA TA-3'; caspase-3: 5'-ATG GAG AAC ACT GAA AAC TCA G-3', 5'-GAC CGA GAT GTC ATT CCA GTG-3'; GAPDH: 5'-GAA GGT GAA GGT CGG AGT C-3', 5'-GAA GAT GGT GAT GGG ATT TC-3'. The reaction was repeated 3 times and carried out in an ABI7500 Real-time PCR System (Applied Biosystems, Carlsbad, CA, USA). Templates were initially denatured at $95^{\circ} \mathrm{C}$ for $5 \mathrm{~min}$ followed by 40 cycles at $95^{\circ} \mathrm{C}$ for $5 \mathrm{sec}$ and $60^{\circ} \mathrm{C}$ for $34 \mathrm{sec}$. The relative expression levels of tested genes were calculated using the $2^{-\Delta \Delta C T}$ method.

Flow cytometry analysis of the cell cycle. PI staining followed by flow cytometry was used to assess the effect of SPS on the cell cycle of A549 and YTMLC-90 cells. Cells were treated with different concentrations of SPS for $48 \mathrm{~h}$. Cells were then washed with cold PBS with $75 \%$ ethanol for $1 \mathrm{~h}$ at $4{ }^{\circ} \mathrm{C}$. The protocol was then followed as previously described (18). Cells were suspended in $1 \mathrm{ml}$ of PBS that contained $1 \mathrm{mg} / \mathrm{ml}$ RNase and $50 \mu \mathrm{g} / \mathrm{ml} \mathrm{PI}$, followed by $30 \mathrm{~min}$ of shaking at $37^{\circ} \mathrm{C}$ in the dark. DNA content was detected using a flow cytometer (BD FACSCalibur System, San Jose, CA, USA).

Western blotting. Protein expression levels of cyclin B1, Cdc25B, PI3K, Akt and p-Akt were measured by western blot according to a previous study (19). After treatment, cells were lysed in RIPA buffer. Protein concentration was determined using the Bradford assay (Bio-Rad, Hercules, CA, USA). Twenty micrograms of protein from each sample were separated by $12 \%$ SDS-PAGE and transferred to PVDF membranes. Primary antibodies (rabbit monoclonal anti-human cyclin B1, 1:3000 dilution; rabbit polyclonal anti-human Cdc25B, 1:1000 dilution; rabbit monoclonal anti-human Akt, 1:1000 dilution; rabbit monoclonal anti-human p-Akt, 1:1000 dilution) were then applied and incubated at $4^{\circ} \mathrm{C}$ overnight, after which the appropriate HRP-conjugated secondary antibody was added and incubated for $1 \mathrm{~h}$ at room temperature. Proteins were detected using the ChemiDoc XRS imaging system and analysis software Quantity One (Bio-Rad).

The effect of SPS injection in vivo. To further analyze the effect of SPS injection in vivo, BALB/c nude mice (7 weeks old) were purchased from Vital River Laboratory Animal Technology Co. Ltd. Murine tumor models were induced by subcutaneous injection of A549 cells ( $5 \times 10^{6}$ cells in $0.2 \mathrm{ml}$ of PBS) at one site in the right flank, and tumors allowed to develop for 20 days. When tumors reached $\sim 100 \mathrm{~mm}^{3}$ in volume, 40 animals were divided randomly into 4 groups $(\mathrm{n}=10$ for each group): low dose $(15 \mathrm{mg} / \mathrm{kg})$, middle dose $(45 \mathrm{mg} / \mathrm{kg})$ and high dose $(135 \mathrm{mg} / \mathrm{kg})$ injection groups, and a control group that was treated with an equal volume of normal saline 
A

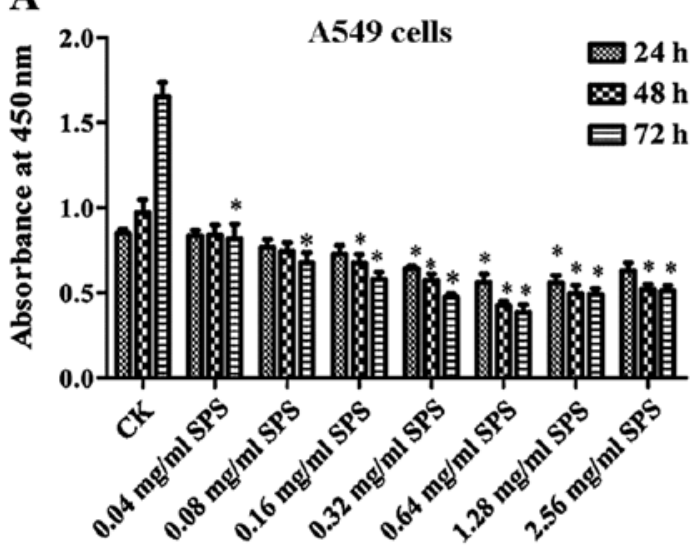

C

A549 cells

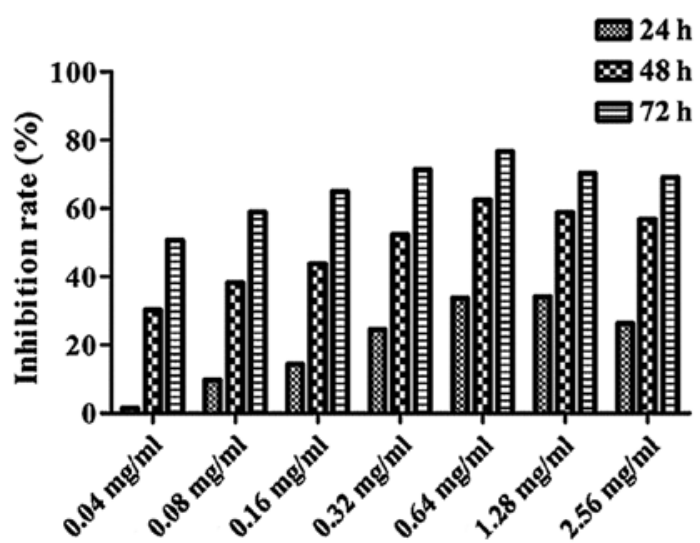

B

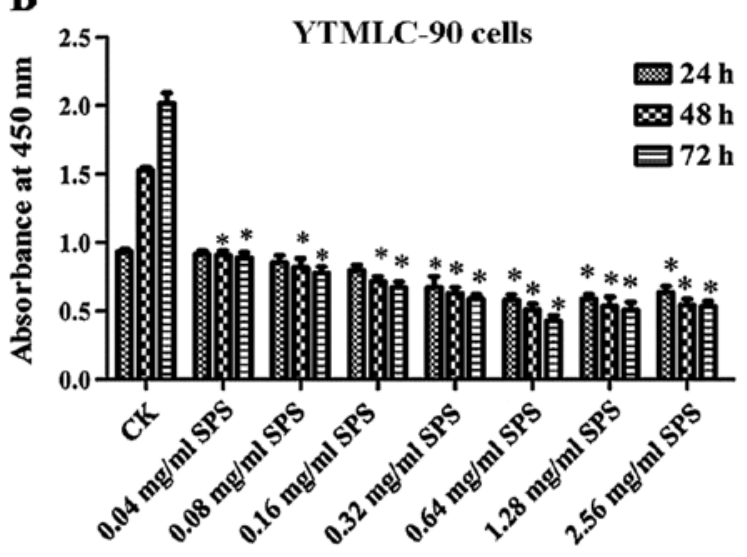

D

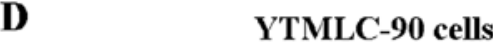

$24 \mathrm{~h}$ $\infty 48 h$ Е72 h

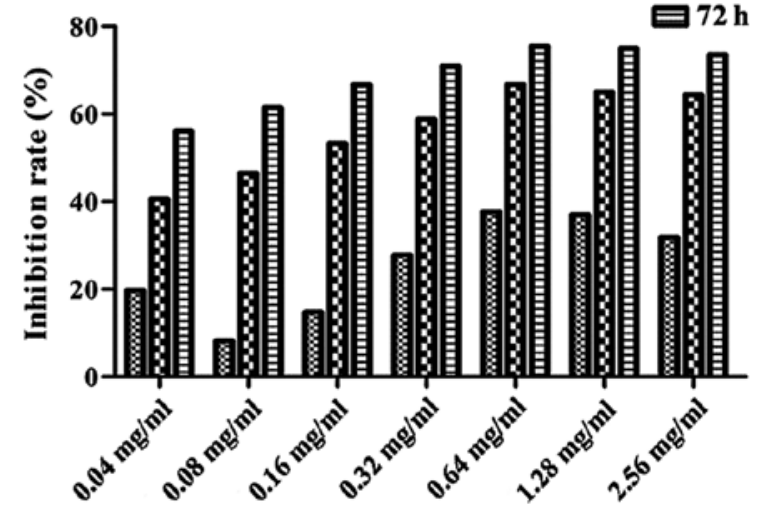

Figure 1. SPS treatment inhibited A549 and YTMLC-90 cell proliferation. Cells were seeded in 96-well plates at a density of 5x10 ${ }^{3}$ cells per well and grown for $24 \mathrm{~h}$. Cells were then treated with various concentrations of SPS ranging from 0.04 to $2.56 \mathrm{mg} / \mathrm{ml}$ for 24,48 , and $72 \mathrm{~h}$. Cell viability of A549 (A) and YTMLC-90 (B) cells was measured using the MTT assay. (C) The inhibition rate of A549 cells. (D) The inhibition rate of YTMLC-90 cells. SPS concentrations: $0.04,0.08,0.16,0.32,0.64,1.28$, and $2.56 \mathrm{mg} / \mathrm{ml} .{ }^{*} \mathrm{P}<0.05$ vs. $\mathrm{CK}$ group.

(NS). All injections were administered intraperitoneally every day. At 15, 20, 25, and 30 days post-injection, tumor size was measured using calipers and tumor volume was estimated according to a previous study (18). Blood samples were taken from a tail vein to measure the contents of TNF- $\alpha$ and IL-6 using ELISA kits.

Statistical analysis. Data were expressed as mean \pm SD and considered significant at $\mathrm{P}<0.05$. Statistical analysis was performed using a Student's unpaired t-test (SPSS release 19.0; SPSS Inc.).

\section{Results}

SPS treatment inhibited A549 and YTMLC-90 cell proliferation. To evaluate the effect of SPS on A549 and YTMLC-90 cell proliferation activity in vitro, an MTT assay was conducted. Results of the MTT assay are shown in Fig. 1A and $\mathrm{B}$. These results demonstrated that the proliferation of A549 and YTMLC-90 cells was inhibited by different concentrations of SPS. Compared with the CK group, concentrations of 0.04 to $2.56 \mathrm{mg} / \mathrm{ml}$ of SPS suppressed the viability of A549 and YTMLC-90 cells, with the exception of $0.04 \mathrm{mg} / \mathrm{ml}$ at $24 \mathrm{~h}(\mathrm{P}<0.05)$. According to Fig. $1 \mathrm{C}$ and $\mathrm{D}$, a time-dependent inhibitory effect of SPS on cell survival was found in A549 and YTMLC-90 cells. At $0.64 \mathrm{mg} / \mathrm{ml}$ of SPS, the inhibition rate peaked after $72 \mathrm{~h}$ of treatment, being 76.66 and $75.47 \%$ in A549 and YTMLC-90 cells, respectively. These results suggested that SPS inhibited A549 and YTMLC-90 cell proliferation.

SPS treatment induced A549 and YTMLC-90 apoptosis. Since a significant decrease in cell viability was found after treatment with SPS, we further tested the effect of SPS treatment on apoptosis. The results of Annexin V-FITC/PI staining showed a dose-dependent effect of SPS on apoptosis in A549 and YTMLC-90 cells (Fig. 2A,B). Compared with CK, apoptosis in A549 and YTMLC-90 cells was significantly increased $(\mathrm{P}<0.05)$. Even at $0.64 \mathrm{mg} / \mathrm{ml}$, SPS treatment induced the highest apoptosis rate in both cell lines $(\mathrm{P}<0.05)$. When the treatment concentration was $>0.64 \mathrm{mg} / \mathrm{ml}$, the level of increase in the apoptosis rate was decreased. To further analyze the mechanism of apoptosis, we also investigated expression levels of bax and capase-3. For the two cell lines, expression levels of bax and capase-3 were both notably induced after treatment with various concentrations of SPS. The expression level of bax peaked at $0.64 \mathrm{mg} / \mathrm{ml}$ of SPS treatment, increasing 2.4- and 3.01-fold in A549 and YTMLC-90 cells, respectively, and the transcription level of capase-3 was increased 3.89- and 
A
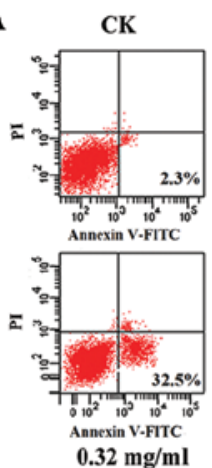

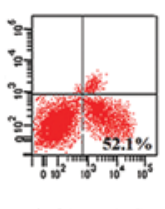

$0.64 \mathrm{mg} / \mathrm{ml}$
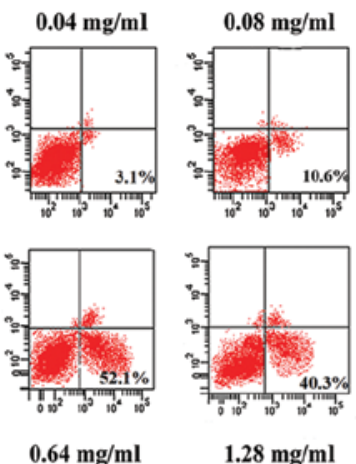
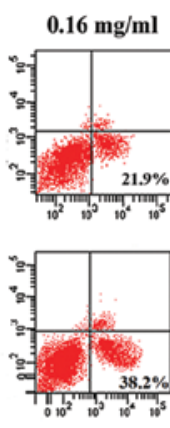

$2.56 \mathrm{mg} / \mathrm{ml}$
B
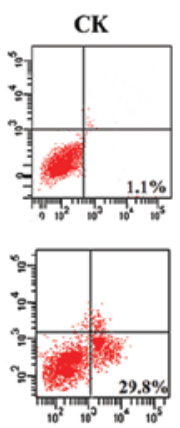

$0.32 \mathrm{mg} / \mathrm{ml}$
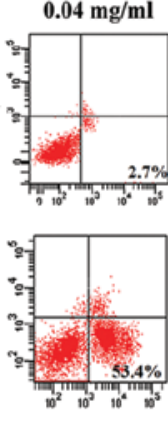

$0.64 \mathrm{mg} / \mathrm{ml}$
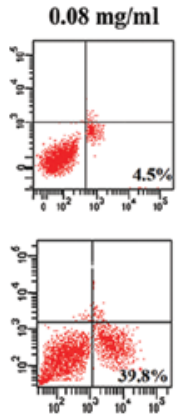

$1.28 \mathrm{mg} / \mathrm{ml}$
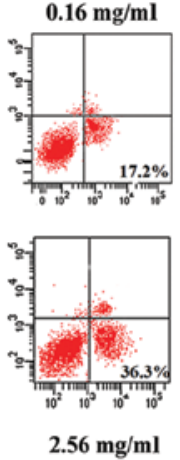
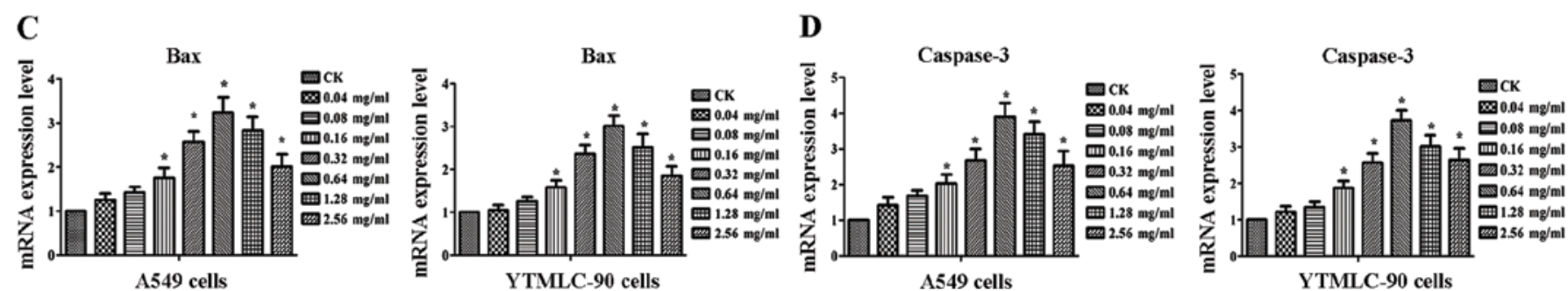

Figure 2. SPS treatment induced apoptosis in A549 and YTMLC-90 cells. Cells were cultured in 6-well plates at a density of $2 \times 10^{5} / \mathrm{ml}$ per well overnight. Cells were treated with various concentrations of SPS ranging from $0.04-2.56 \mathrm{mg} / \mathrm{ml}$ for $48 \mathrm{~h}$. Control cells were treated with culture media containing DMSO. (A and B) Apoptosis in A549 and YTMLC-90 cells after various concentrations of SPS treatment for $48 \mathrm{~h}$ and Annexin V-FITC/PI staining assay. (C and D) Transcription levels of bax and capase-3 in A549 and YTMLC-90 cells were measured by real-time PCR. SPS concentrations: 0.04, 0.08, 0.16, 0.32, $0.64,1.28$, and $2.56 \mathrm{mg} / \mathrm{ml}$. All data are shown as mean $\pm \mathrm{SD}$. ${ }^{*} \mathrm{P}<0.05$ vs. CK group.

Table I. SPS induced A549 cell cycle arrest in G2/M phase.

\begin{tabular}{lccc}
\hline & \multicolumn{3}{c}{ Cell cycle distribution (\%) } \\
\cline { 2 - 4 } A549 cells/Groups & G1/G0 & S & G2/M \\
\hline CK & 65.7 & 23.2 & 11.1 \\
$0.04 \mathrm{mg} / \mathrm{ml} \mathrm{SPS}$ & 62.3 & 24.5 & 13.2 \\
$0.08 \mathrm{mg} / \mathrm{ml} \mathrm{SPS}$ & 59.2 & 20.9 & 19.9 \\
$0.16 \mathrm{mg} / \mathrm{ml} \mathrm{SPS}$ & 53.2 & 15.3 & 31.5 \\
$0.32 \mathrm{mg} / \mathrm{ml} \mathrm{SPS}$ & 42.9 & 12.6 & 44.5 \\
$0.64 \mathrm{mg} / \mathrm{ml} \mathrm{SPS}$ & 29.3 & 10.4 & 60.3 \\
$1.28 \mathrm{mg} / \mathrm{ml} \mathrm{SPS}$ & 32.6 & 12.7 & 54.7 \\
$2.56 \mathrm{mg} / \mathrm{ml} \mathrm{SPS}$ & 39.8 & 16.9 & 43.3 \\
\hline
\end{tabular}

3.72-fold, respectively (Fig. 2C and D). This result was consistent with the apoptosis rate. In brief, SPS induced apoptosis in A549 and YTMLC-90 cells.

SPS treatment induced A549 and YTMLC-90 cell cycle arrest in the G2/M phase. To further analyze the effect of SPS treatment on the cell cycle, we examined both mRNA and protein expression levels of cdc25B and cyclin B1 (Fig. 3). The results of real-time PCR showed that after treatment with SPS, the expression levels of cdc25B and cyclin B1 were both decreased with increasing concentration of SPS when compared with the CK group in A549 and YTMLC-90 cells, reaching their lowest levels at $0.64 \mathrm{mg} / \mathrm{ml}$ SPS (Fig. 3A and C). Western blot results also confirmed that the activity of cdc25B and cyclin B1 were both decreased, especially after treatment with $0.64 \mathrm{mg} / \mathrm{ml}$ of SPS in A549 or TYMLC-90 cells (Fig. 3B and D). As shown in
Table II. SPS induced YTMLC-90 cell cycle arrest in G2/M phase.

\begin{tabular}{lccr}
\hline & \multicolumn{3}{c}{ Cell cycle distribution (\%) } \\
\cline { 2 - 4 } YTMLC-90 cells/Groups & G1/G0 & \multicolumn{1}{c}{$\mathrm{S}$} & G2/M \\
\hline CK & 68.2 & 27.6 & 4.2 \\
$0.04 \mathrm{mg} / \mathrm{ml} \mathrm{SPS}$ & 65.9 & 25.7 & 8.4 \\
$0.08 \mathrm{mg} / \mathrm{ml} \mathrm{SPS}$ & 60.3 & 20.9 & 18.8 \\
$0.16 \mathrm{mg} / \mathrm{ml} \mathrm{SPS}$ & 53.6 & 15.7 & 30.7 \\
$0.32 \mathrm{mg} / \mathrm{ml} \mathrm{SPS}$ & 42.1 & 12.3 & 45.6 \\
$0.64 \mathrm{mg} / \mathrm{ml} \mathrm{SPS}$ & 28.9 & 9.3 & 61.8 \\
$1.28 \mathrm{mg} / \mathrm{ml} \mathrm{SPS}$ & 34.6 & 14.9 & 50.5 \\
$2.56 \mathrm{mg} / \mathrm{ml} \mathrm{SPS}$ & 40.2 & 18.3 & 41.5 \\
\hline
\end{tabular}

Table I and Table II, when cells were treated with SPS for $48 \mathrm{~h}$, their DNA contents were significantly increased in the G2/M phase. In the $0.64 \mathrm{mg} / \mathrm{ml} \mathrm{SPS} \mathrm{treatment} \mathrm{group,} \mathrm{DNA} \mathrm{content}$ was markedly increased from 11.1 to $60.3 \%$ in A549 cells, and from 4.2 to $61.8 \%$ in YTMLC-90 cells. In contrast, the G0/ G1 phase population in the SPS treatment group decreased from 65.7 to $29.3 \%$ in A549 cells, and from 68.2 to $28.9 \%$ in YTMLC-90 cells. These results suggested that SPS induced cell cycle arrest in the $\mathrm{G} 2 / \mathrm{M}$ phase.

SPS treatment inhibited the Akt pathway. To investigate whether the inhibitory effect of SPS treatment on NSCLC cell proliferation was mediated by the PI3K/Akt pathway, we analyzed protein expression levels of the PI3K/Akt pathway. In these experiments, cells were treated with SPS $(0.04,0.64$, 
A

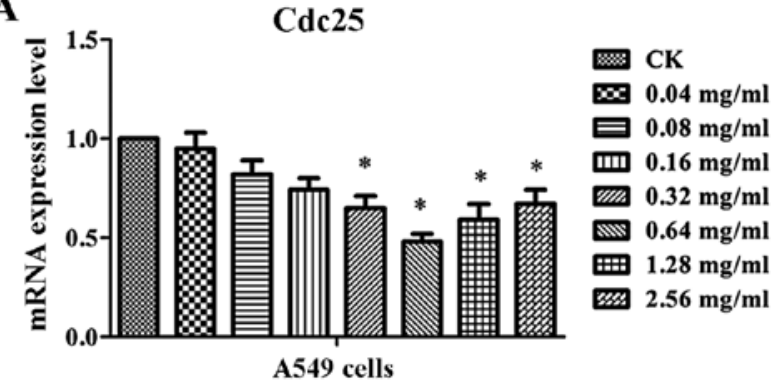

B

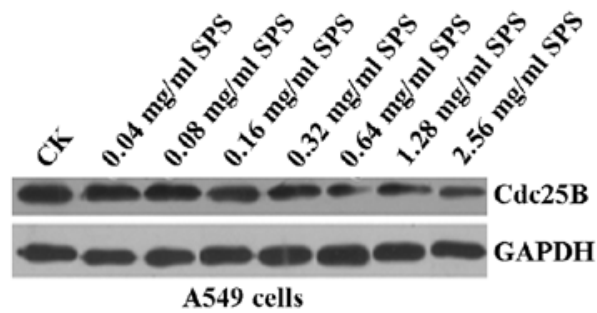

C

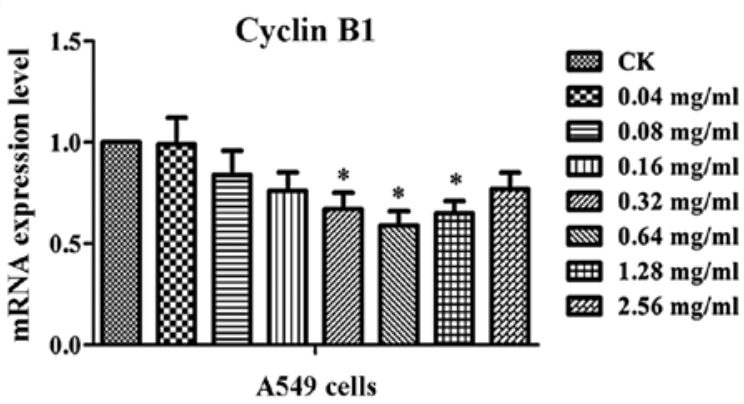

D

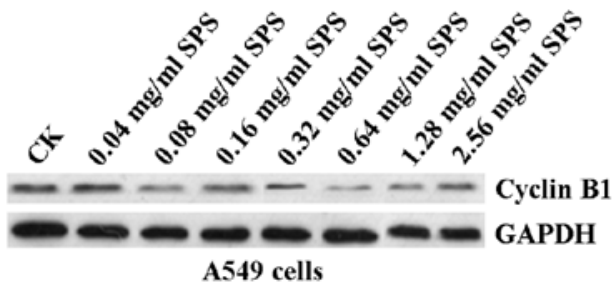

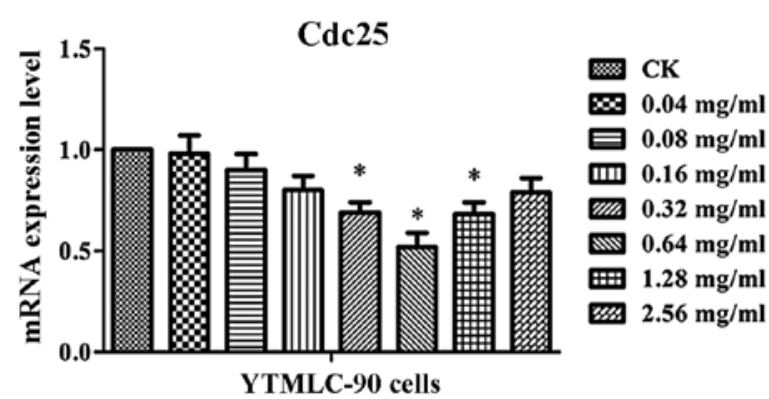
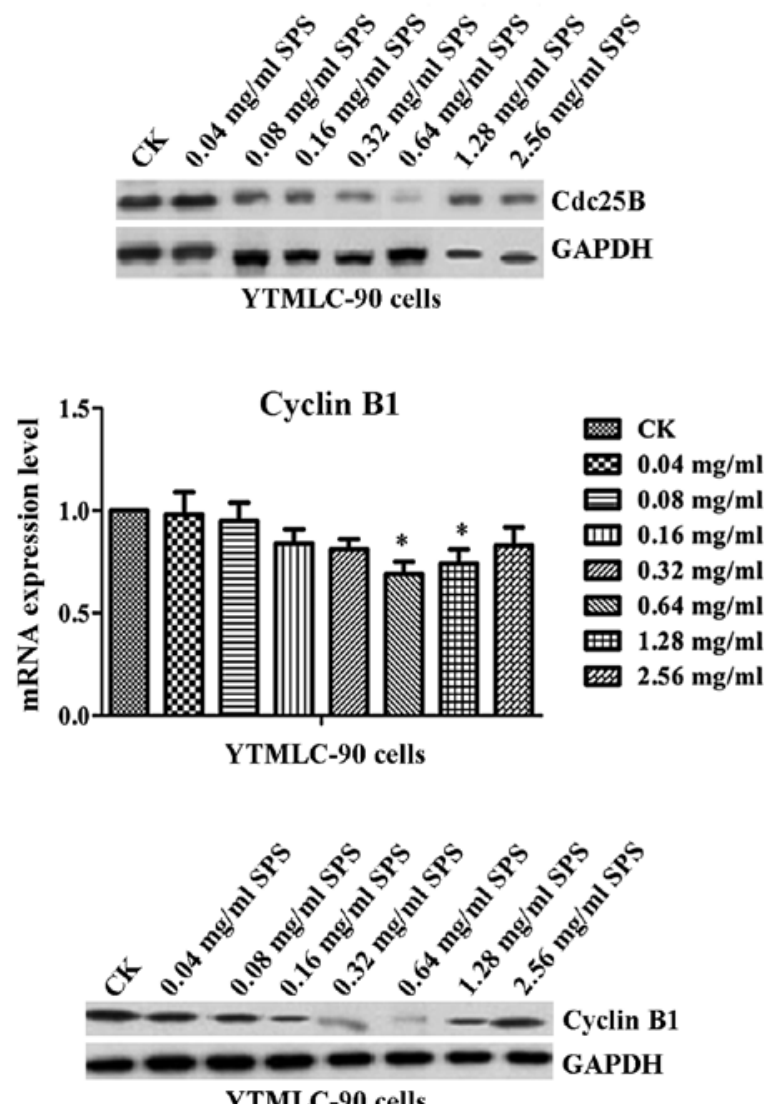

YTMLC-90 cells

Figure 3. SPS treatment induced A549 and YTMLC-90 cell cycle arrest in the G2/M phase. Cells were then treated with various concentrations of SPS ranging from 0.04 to $2.56 \mathrm{mg} / \mathrm{ml}$ for $48 \mathrm{~h}$. Flow cytometry was used to assess the effect of SPS on the cell cycle in A549 and YTMLC-90 cells. (A) The expression level of $c d c 25 B$ in A549 and YTMLC-90 was measured by real-time PCR. (B) The protein expression level of cdc25B in A549 and YTMLC-90 cells was measured by western blotting. (C) The expression level of cyclin B1 in A549 and YTMLC-90 cells was measured by real-time PCR. (D) The protein expression level of cyclin $\mathrm{B} 1$ in A549 and YTMLC-90 cells was measured by western blotting. SPS concentrations: $0.04,0.08,0.16,0.32,0.64$ and $2.56 \mathrm{mg} / \mathrm{ml}$. "P<0.05 vs. CK group.

and $2.56 \mathrm{mg} / \mathrm{ml}$ ) for $48 \mathrm{~h}$. As seen in Fig. 4, we found that compared with the CK group, $0.04 \mathrm{mg} / \mathrm{ml}$ of SPS treatment had no effect on the expression of Akt, p-Akt, and PI3K, whereas $0.64 \mathrm{mg} / \mathrm{ml}$ of SPS treatment markedly decreased the expression of Akt, p-Akt and PI3K; $2.56 \mathrm{mg} / \mathrm{ml}$ of SPS treatment also decreased the expression of these four proteins, but the decreased level was lower than in the $0.64 \mathrm{mg} / \mathrm{ml}$ group. This result suggested that SPS inhibited NSCLC cell proliferation by decreasing protein expression levels of the PI3K/Akt pathway.

SPS injection inhibited tumor growth and improved immunomodulatory activities in BALB/c nude mice. BALB/c nude mice were used to determine the anti-lung cancer effect of SPS in vivo. Mice were injected with different concentrations of SPS $(15,45$, and $135 \mathrm{mg} / \mathrm{kg})$. As shown in Fig. 5A, compared with the control group, SPS injection significantly decreased tumor volume $(\mathrm{P}<0.05)$. SPS injection of $45 \mathrm{mg} / \mathrm{kg}$ and $135 \mathrm{mg} / \mathrm{kg}$ dramatically suppressed tumor growth, with the inhibition rate reaching 75 and 65\% 25 days after injection (Fig. 5B). This result indicated that SPS inhibited tumor growth in mice. TNF- $\alpha$ and IL-6 levels were measured to evaluate the immunomodulatory activities of SPS injection in mice. According to Fig. 5C and D, SPS significantly increased TNF- $\alpha$ and IL-6 levels when compared with the control group $(\mathrm{P}<0.05)$. For instance, 30 days after injection of SPS $(45 \mathrm{mg} / \mathrm{kg}$ ) in mice, TNF- $\alpha$ was increased by $33.55 \%$, relative to the control group. The level of IL-6 in the $45 \mathrm{mg} / \mathrm{kg}$ SPS injection group was increased by $39.50 \%$ relative to the control group. These results indicated that SPS injection increased immunomodulatory activities in mice in vivo, suggesting a potential antitumor application in tumor-bearing mice. 


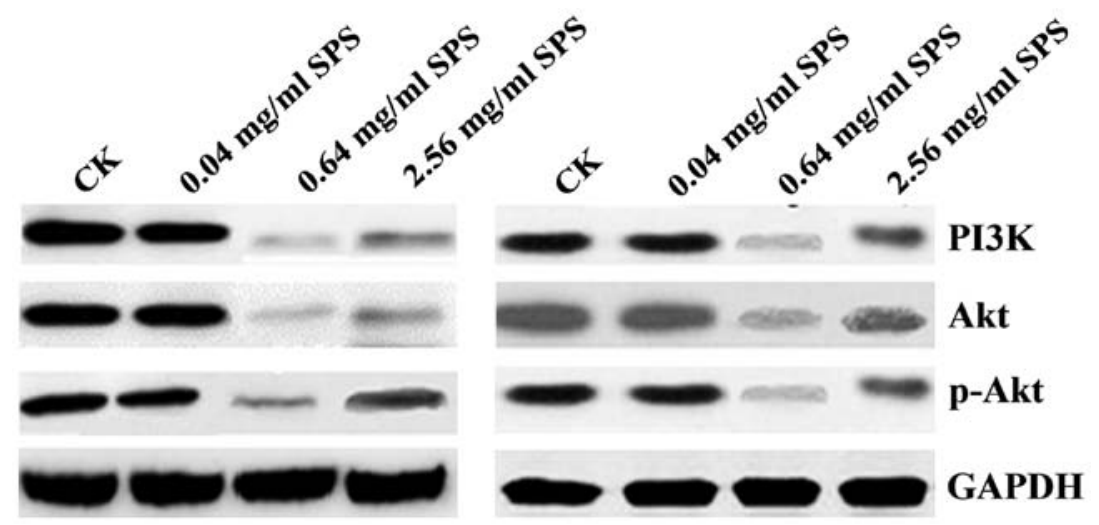

Figure 4. SPS treatment decreased expression levels of PI3K/Akt pathway-related proteins in A549 and YTMLC-90 cells. After A549 and YTMLC-90 cells were treated with SPS $(0.04,0.64$, and $2.56 \mathrm{mg} / \mathrm{ml})$ for $48 \mathrm{~h}$, expression levels of PI3K, Akt, and p-Akt were measured by western blotting.

A

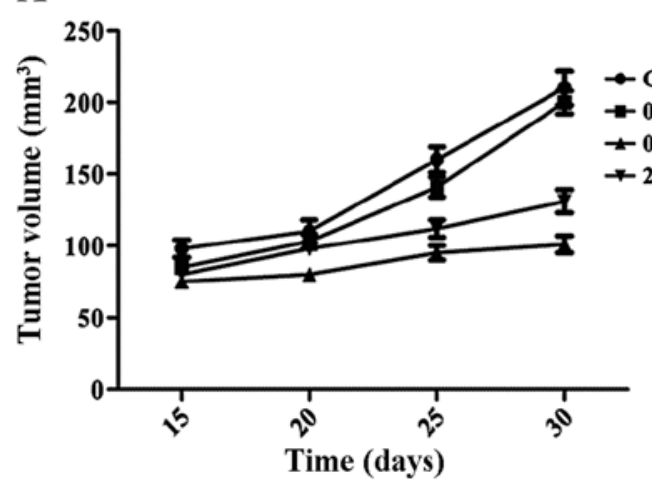

C

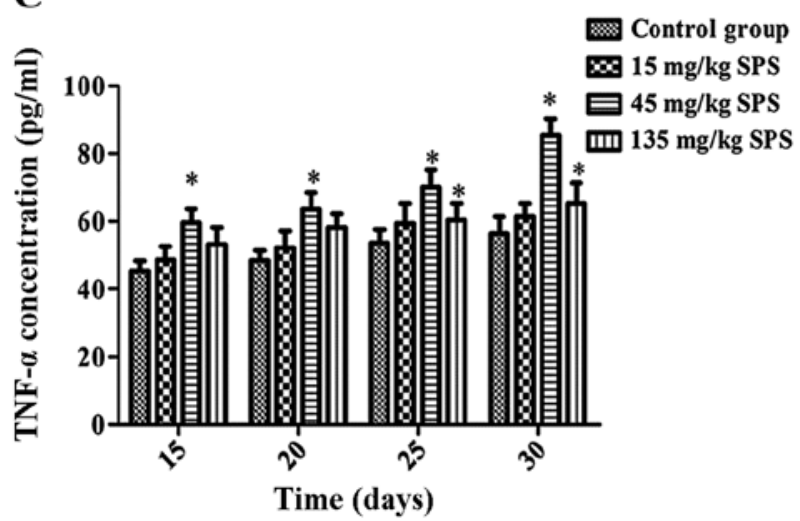

\section{B}

D
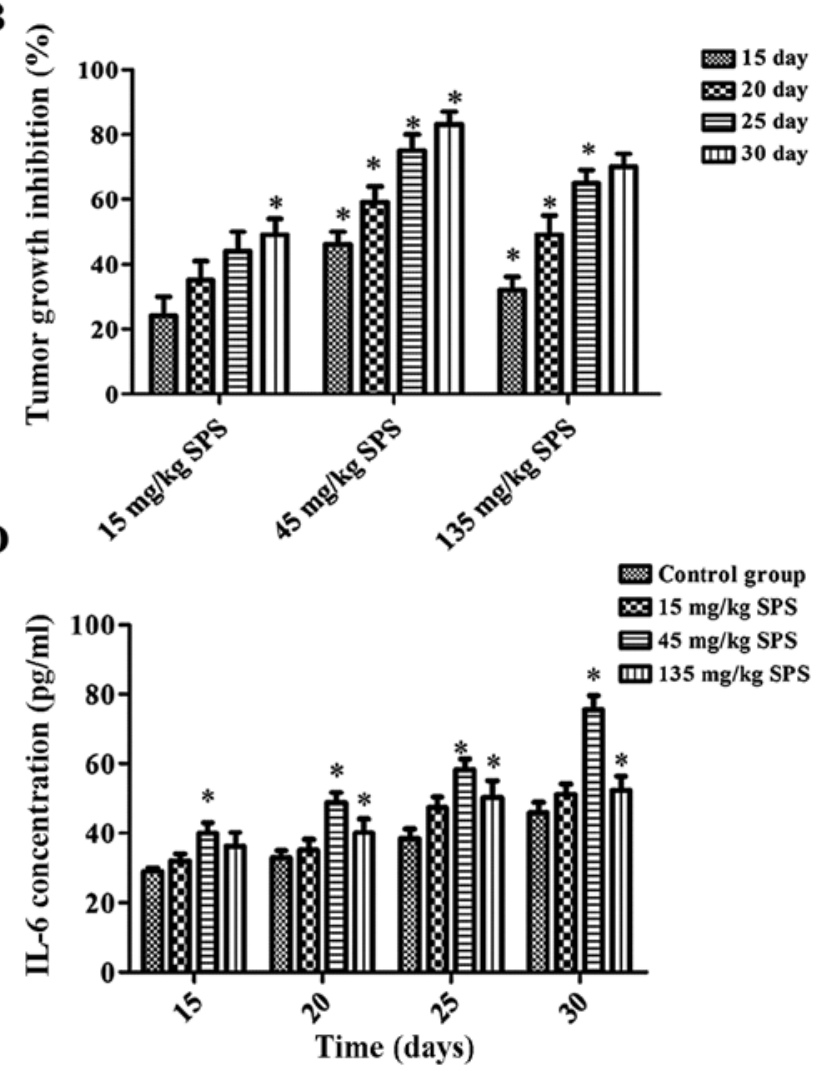

Figure 5. SPS treatment increased immunomodulatory activities in tumor bearing mice. Murine tumor models were induced by subcutaneous injection of A549 cells $\left(5 \times 10^{6}\right.$ cells in $0.2 \mathrm{ml}$ of PBS) at one site in the right flank. When the tumor reached $\sim 100 \mathrm{~mm}^{3}$ in volume, 40 animals were divided randomly into 4 groups ( $\mathrm{n}=10$ for each group): low $(15 \mathrm{mg} / \mathrm{kg})$, middle $(45 \mathrm{mg} / \mathrm{kg})$ and high $(135 \mathrm{mg} / \mathrm{kg})$ dose groups, and a control group that was treated with an equal volume of normal saline (NS). All injections were administered intraperitoneally every day. (A) Tumor volume was measured $15,20,25$, and 30 days after SPS injection. (B) The inhibition rate of tumor growth. (C) TNF- $\alpha$ concentration (pg/ml) was assayed by ELISA 15, 20, 25, and 30 days after SPS injection. (D) IL-6 concentration (pg/ml) was assayed by ELISA 15, 20, 25, and 30 days after SPS injection. SPS concentrations: 15 , 45 , and $135 \mathrm{mg} / \mathrm{kg}$. All data are expressed as mean $\pm \mathrm{SD}(\mathrm{n}=10)$. ${ }^{*} \mathrm{P}<0.05$ vs. CK group.

\section{Discussion}

Safflower is a herb medicine famous for its ability to improve blood circulation and blood stasis and relieve pain. So far, the anticancer effects of safflower have been focused on safflower yellow, which is a kind of flavonoids $(11,20)$. The antitumor effect of SPS is rarely reported, apart from one study indicating that SPS inhibited the proliferation and metastasis of
MCF-7 breast cancer cells (16). In this study, the effect of SPS in human NSCLC was investigated. Results of the MTT assay suggested that SPS suppressed the proliferation of A549 and YTMLC-90 cells and exhibited a dose-dependent effect; in particular, the inhibition rate in the $0.64 \mathrm{mg} / \mathrm{ml}$ SPS group reached 76.66 and $75.47 \%$ in A549 and YTMLC-90 cells, respectively. Results of the apoptosis assay also showed that SPS induced cell apoptosis and exhibited a dose-dependent 
effect. Moreover, expression levels of bax and capase-3 were increased after treatment with SPS. In recent years, more and more plant polysaccharides have been used in antitumor studies. For example, cactus polysaccharides induced growth arrest and apoptosis in lung squamous carcinoma cells (21). Pleurotus nebrodensis polysaccharide induced apoptosis in A549 cells (22). Scutellaria Barbata D. polysaccharides showed anti-tumor growth activity on human lung cancer 95-D (23). In our study, SPS induced apoptosis in NSCLC cells and increased expression levels of bax and capase-3.

Cell viability and apoptosis were dose- and time-dependent within the range of 0.04 to $0.64 \mathrm{mg} / \mathrm{ml}$ of SPS treatment. When the dose of SPS was higher than $0.64 \mathrm{mg} / \mathrm{ml}$, the rate of increase declined. It is well known that $\mathrm{Na}^{+} / \mathrm{K}^{+}$-ATPase activity is an important indicator of erythrocyte viability and is downregulated in tumor cells (24). For example, $L$. barbarum polysaccharides prevented the development of cardiovascular disease by increasing the activity of $\mathrm{Na}^{+}-\mathrm{K}^{+}-$ ATPase in heart ischemia reperfusion (IR) in rats (25). Sargassum fusiforme polysaccharides (SFPS) could restore some biochemical functions of erythrocyte membranes in $S_{180}$ mice by increasing $\mathrm{Na}^{+}-\mathrm{K}^{+}$-ATPase activity (26). SPS may play a similar role to that of $L$. barbarum polysaccharides and SFPS. $\mathrm{Na}^{+}-\mathrm{K}^{+}$-ATPase activity may be increased when cells are treated with various concentrations of SPS within the range of 0.04 to $0.64 \mathrm{mg} / \mathrm{ml}$, but when the concentration is greater than $0.64 \mathrm{mg} / \mathrm{ml}, \mathrm{Na}^{+}-\mathrm{K}^{+}$-ATPase activity may be decreased. $\mathrm{Na}^{+}-\mathrm{K}^{+}$-ATPase is very sensitive and regulated in a dose-dependent manner by some drugs, such as ouabain. In this study, SPS within a certain range of concentrations may also have influenced $\mathrm{Na}^{+}-\mathrm{K}^{+}$-ATPase activity in a dosedependent manner.

SPS induced A549 and YTMLC-90 cell cycle arrest at the $\mathrm{G} 2 / \mathrm{M}$ phase. Cyclin $\mathrm{B} 1$ and $\mathrm{cdc} 25 \mathrm{~B}$ are upregulated in tumor cells and are crucial for the cell cycle. In recent years, many studies have demonstrated that plant polysaccharides induced cell cycle arrest at the G2/M phase by regulating cell cycle-related protein expression. Polysaccharides from Masson pine pollen induced cell cycle arrest at the G2/M phase by downregulating expression levels of CDK1 and Cyclin B (27). Wolfberry (Lycium barbarum) polysaccharide induced cell cycle arrest at the G0/G1 phase and the expression of cyclins and CDKs was consistent with changes in cell cycle distribution (28). In this study, we also found that both transcription and protein levels of cdc25B and cyclin B1 were decreased with increasing concentration of SPS treatment. This result indicated that SPS induced cell cycle arrest at the $\mathrm{G} 2 / \mathrm{M}$ phase by downregulating expression levels of $\operatorname{cdc} 25 \mathrm{~B}$ and cyclin B1.

SPS inhibited the Akt pathway. SPS treatment at $0.64 \mathrm{mg} / \mathrm{ml}$ markedly decreased the expression of Akt, $\mathrm{p}-\mathrm{Akt}$ and PI3K. Inhibition of the PI3K/Akt pathway prevented tumor cell proliferation. Such as Astragalus polysaccharide could ameliorate doxorubicin-mediated cardiotoxicity via regulation of the PI3k/Akt pathway (29). Glycyrrhiza polysaccharide induced apoptosis and inhibited proliferation in human hepatocellular carcinoma cells by blocking the PI3K/ Akt pathway (30). Our study also showed that SPS suppressed the PI3K/Akt pathway by decreasing expression levels of PI3K, Akt and p-Akt. To summarize, SPS inhibited NSCLC cell proliferation and induced apoptosis by suppressing the PI3K/Akt pathway.

SPS increased immunomodulatory activities by raising the levels of TNF- $\alpha$ and IL- 6 . The improvement of immunomodulatory activities in cancer by medicinal plant polysaccharides has been widely investigated. For example, a water-soluble polysaccharide from Chaenomeles speciosa increased antitumor and immunomodulatory activities in tumor-bearing mice (31). Polysaccharides from Cymbopogon citratus increased immunomodulatory activities by raising levels of TNF- $\alpha$, IL-2, and IL-6 in transplanted S180 tumors (32). Polysaccharide fractions from safflower petals stimulated the production of IL-1, IL- 6 and TNF- $\alpha$ and increased immunomodulatory activity (33). Our results also showed that SPS significantly increased levels of TNF- $\alpha$ and IL-6. We posit that the antitumor activity of SPS may be due to its positive influence on TNF- $\alpha$ and IL- 6 expression.

Taken together, our results suggest that, on the one hand, SPS induces cell cycle arrest at the G2/M phase by decreasing expression levels of cyclin B1 and cdc25B. On the other hand, SPS induces A549 and YTMLC-90 apoptosis by decreasing expression levels of capase-3 and bax. The underlying mechanism of apoptosis may involve blocking the PI3K/Akt pathway or increasing immunomodulatory activities. Therefore, SPS may have therapeutic implications for the clinical management of lung cancer.

\section{Acknowledgements}

This work was supported by the Natural Science Foundation of Shaanxi Province (2012JC2-06) and Shaanxi Science and Technology Plan Projects Fund (2014K11-01-02-15).

\section{References}

1. Lev-Ari S, Starr A, Katzburg S, Berkovich L, Rimmon A, Ben-Yosef R, Vexler A, Ron I and Earon G: Curcumin induces apoptosis and inhibits growth of orthotopic human non-small cell lung cancer xenografts. J Nutr Biochem 25: 843-850, 2014.

2. Liloglou T, Bediaga NG, Brown BR, Field JK and Davies MP: Epigenetic biomarkers in lung cancer. Cancer Lett 342: 200-212, 2014

3. Hennessy BT, Smith DL, Ram PT, Lu Y and Mills GB: Exploiting the PI3K/AKT pathway for cancer drug discovery. Nat Rev Drug Discov 4: 988-1004, 2005.

4. Zhu Z, Sun H, Ma G, Wang Z, Li E, Liu Y and Liu Y: Bufalin induces lung cancer cell apoptosis via the inhibition of PI3K/ Akt pathway. Int J Mol Sci 13: 2025-2035, 2012.

5. Zhang X-Y, Kuang J-L, Yan C-S, Tu XY, Zhao JH, Cheng XS and Ye XQ: NRSN2 promotes non-small cell lung cancer cell growth through PI3K/Akt/mTOR pathway. Int J Clin Exp Pathol 8: 2574-2581, 2015.

6. Chew CL, Lunardi A, Gulluni F, Ruan DT, Chen M, Salmena L, Nishino M, Papa A, Ng C, Fung J, et al: In vivo role of INPP4B in tumor and metastasis suppression through regulation of PI3K/AKT signaling at endosomes. Cancer Discov 5: 740-751, 2015.

7. Xu X, Zhang Y, Qu D, Jiang T and Li S: Osthole induces G2/M arrest and apoptosis in lung cancer A549 cells by modulating PI3K/Akt pathway. J Exp Clin Cancer Res 30: 33, 2011.

8. Hou Z, Zhao W, Zhou J, Shen L, Zhan P, Xu C, Chang C, Bi H, Zou J, Yao X, et al: A long noncoding RNA Sox2ot regulates lung cancer cell proliferation and is a prognostic indicator of poor survival. Int J Biochem Cell Biol 53: 380-388, 2014.

9. Tian T, Li J, Li B, Wang Y, Li M, Ma D and Wang X: Genistein exhibits anti-cancer effects via down-regulating FoxM1 in H446 small-cell lung cancer cells. Tumour Biol 35: 4137-4145, 2014. 
10. Zhou X, Tang L, Xu Y, Zhou G and Wang Z: Towards a better understanding of medicinal uses of Carthamus tinctorius L. in traditional Chinese medicine: A phytochemical and pharmacological review. J Ethnopharmacol 151: 27-43, 2014.

11. Fan S, Lin N, Shan G, Zuo P and Cui L: Safflower yellow for acute ischemic stroke: A systematic review of randomized controlled trials. Complement Ther Med 22: 354-361, 2014.

12. Li LJ, Li YM, Qiao BY, Jiang S, Li X, Du HM, Han PC and Shi J: The value of safflower yellow injection for the treatment of acute cerebral infarction: A randomized controlled trial. Evid Based Complement Alternat Med 2015: 478793, 2015.

13. Liu Y, Tian X, Cui M and Zhao S: Safflower yellow inhibits angiotensin II-induced adventitial fibroblast proliferation and migration. J Pharmacol Sci 126: 107-114, 2014.

14. Toma W, Guimarães LL, Brito AR, Santos AR, Cortez FS Pusceddu FH, Cesar A, Júnior LS, Pacheco MTT and Pereira CDS: Safflower oil: An integrated assessment of phytochemistry, antiulcerogenic activity, and rodent and environmental toxicity. Rev Bras Farmacogn 24: 538-544, 2014.

15. Ali Sahari M, Morovati N, Barzegar M and Asgari S: Physicochemical and antioxidant characteristics of safflower seed oil. Curr Nutr Food Sci 10: 268-274, 2014.

16. Luo Z, Zeng H, Ye Y, Liu L, Li S, Zhang J and Luo R: Safflower polysaccharide inhibits the proliferation and metastasis of MCF-7 breast cancer cell. Mol Med Rep 11: 4611-4616, 2015.

17. Sabah FS and Saleh AA: Evaluation of antibacterial activity of flavonoid and oil extracts from safflower (Carthamus tinctorius L.). J Nat Sci Res 5: 41-44, 2015.

18. Yu J, Sun R, Zhao Z and Wang Y: Auricularia polytricha polysaccharides induce cell cycle arrest and apoptosis in human lung cancer A549 cells. Int J Biol Macromol 68: 67-71, 2014.

19. Kim Y-J, Choi W-I, Jeon B-N, Choi KC, Kim K, Kim TJ, Ham J, Jang HJ, Kang KS and Ko H: Stereospecific effects of ginsenoside $20-R g 3$ inhibits TGF- $\beta 1$-induced epithelial-mesenchymal transition and suppresses lung cancer migration, invasion and anoikis resistance. Toxicology 322: 23-33, 2014.

20. Xi SY, Zhang Q, Liu CY, Xie H, Yue LF and Gao XM: Effects of hydroxy safflower yellow-A on tumor capillary angiogenesis in transplanted human gastric adenocarcinoma BGC-823 tumors in nude mice. J Tradit Chin Med 32: 243-248, 2012.

21. Li W, Wu D, Wei B, Wang S, Sun H, Li X, Zhang F, Zhang C and Xin Y: Anti-tumor effect of cactus polysaccharides on lung squamous carcinoma cells (SK-MES-1). Afr J Tradit Complement Altern Med 11: 99-104, 2014

22. Cui H, Wang C, Wang Y, Li Z, Zhang Y, Chen M and Li F: Pleurotus nebrodensis polysaccharide induces apoptosis in human non-small cell lung cancer A549 cells. Carbohydr Polym 104: 246-252, 2014.
23. Yang X, Yang Y, Tang S, Tang H, Yang G, Xu Q and Wu J: Anti-tumor effect of polysaccharides from Scutellaria barbata $\mathrm{D}$. Don on the 95-D xenograft model via inhibition of the C-met pathway. J Pharmacol Sci 125: 255-263, 2014

24. Sousa L, Garcia IJ, Costa TG, Silva LN, Renó CO, Oliveira ES, Tilelli CQ, Santos LL, Cortes VF, Santos HL, et al: Effects of iron overload on the activity of Na,K-ATPase and lipid profile of the human erythrocyte membrane. PLoS One 10: e0132852, 2015.

25. Lu S-P and Zhao P-T: Chemical characterization of Lycium barbarum polysaccharides and their reducing myocardial injury in ischemia/reperfusion of rat heart. Int J Biol Macromol 47: 681-684, 2010.

26. Ji Y, Ji C and Wang C: Study on S180 Tumor Mice Erythrocyte Membrance Function of Sargassum Fusiform Polysaccharides. In: 7th Asian-Pacific Conference on Medical and Biological Engineering Springer, pp531-533, 2008. https://www. researchgate.net/publication/226856649_Study_on_S180_ Tumor_Mice_Erythrocyte_Membrance_Function_of_ Sargassum_Fusiform_Polysaccharides.

27. Chu H-L, Mao H, Feng W, Liu JW and Geng Y: Effects of sulfated polysaccharide from Masson pine (Pinus massoniana) pollen on the proliferation and cell cycle of HepG2 cells. Int J Biol Macromol 55: 104-108, 2013.

28. Mao F, Xiao B, Jiang Z, Zhao J, Huang X and Guo J: Anticancer effect of Lycium barbarum polysaccharides on colon cancer cells involves G0/G1 phase arrest. Med Oncol 28: 121-126, 2011.

29. Cao Y, Ruan Y, Shen T, Huang X, Li M, Yu W, Zhu Y, Man Y, Wang $\mathrm{S}$ and Li J: Astragalus polysaccharide suppresses doxorubicin-induced cardiotoxicity by regulating the PI3k/Akt and p38MAPK pathways. Oxid Med Cell Longev 2014: 674219, 2014.

30. Chen J, Jin X, Chen J and Liu C: Glycyrrhiza polysaccharide induces apoptosis and inhibits proliferation of human hepatocellular carcinoma cells by blocking PI3K/AKT signal pathway. Tumour Biol 34: 1381-1389, 2013.

31. Xie X, Zou G and Li C: Antitumor and immunomodulatory activities of a water-soluble polysaccharide from Chaenomeles speciosa. Carbohydr Polym 132: 323-329, 2015.

32. Bao XL, Yuan HH, Wang CZ, Fan W and Lan MB Polysaccharides from Cymbopogon citratus with antitumor and immunomodulatory activity. Pharm Biol 53: 117-124, 2015.

33. Wakabayashi T, Hirokawa S, Yamauchi N, Kataoka T, Woo JT and Nagai K: Immunomodulating activities of polysaccharide fractions from dried safflower petals. Cytotechnology 25: 205-211, 1997. 